\title{
Growth curve of Balloniscus glaber Araujo \& Zardo (Crustacea, Isopoda, Oniscidea) from Parque Estadual de Itapuã, Rio Grande do Sul, Brazil ${ }^{1}$
}

\author{
Helena Meinhardt ${ }^{2}$; Aline F. Quadros ${ }^{2} \&$ Paula B. Araujo ${ }^{2}$
}

\begin{abstract}
${ }^{1}$ Contribution number 524 of the Departamento de Zoologia, Universidade Federal do Rio Grande do Sul.
2 Departamento de Zoologia, PPG Biologia Animal, Universidade Federal do Rio Grande do Sul, Avenida Bento Gonçalves 9500, prédio 43435, 91501-970 Porto Alegre, Rio Grande do Sul, Brasil.

E-mail: helena_meinhardt@yahoo.com.br; bioaline@gmail.com; pbaraujo@portoweb.com.br
\end{abstract}

\begin{abstract}
Based on field data, this study presents the growth curve of Balloniscus glaber Araujo \& Zardo, 1995, a terrestrial isopod species found in Parque Estadual de Itapuã (PEI), Rio Grande do Sul, Brazil. Specimens were monthly sampled, from May 2004 to April 2005, at PEl. Captured individuals were sexed, their cephalothorax width was measured, and the growth curve was described according to von Bertalanffy's model. Male and female growth curves are described by the equations: $W_{t}=2.256\left[1-e^{-0.00394(t+9.128)}\right]$ and $W_{t}=2.588\left[1-e^{-0.00301(t+101)}\right]$, respectively. Curves show differential growth between males and females, with females reaching higher $\mathrm{W}_{\infty}$, and a slower growth rate than males. Based on theses curves, life span was estimated.
\end{abstract}

KEY WORDS. Life span; terrestrial isopods; Neotropical Region; von Bertalanffy.

RESUMO. Curva de crescimento de Balloniscus glaber Araujo \& Zardo (Crustacea, Isopoda, Oniscidea) no Parque Estadual de Itapuã, Rio Grande do Sul, Brasil. Esse estudo, baseado em dados de campo, esse estudo apresenta a curva de crescimento de Balloniscus glaber Araujo \& Zardo, 1995, um isópodo terrestre encontrado no Parque Estadual de Itapuã (PEI), Rio Grande do Sul. Os espécimes foram coletados mensalmente, de maio de 2004 a abril de 2005, no PEl. Os indivíduos capturados foram sexados e tiveram o cefalotórax mensurado e a curva de crescimento descrita a partir do modelo de von Bertalanffy. As curvas de crescimento para machos e para fêmeas são descritas pelas equações: $L_{t}=2,256\left[1-\mathrm{e}^{-0,00394(t+91,128)}\right]$ e $L_{t}=2,588\left[1-e^{-0,00301(t+10)}\right]$, respectivamente. As curvas apresentam crescimento diferencial entre machos e fêmeas, com fêmeas atingindo maior $L_{\infty}$ mas com uma taxa de crescimento menor do que os machos. Com base na curva foi estimada a longevidade dos animais. PALAVRAS-CHAVE. Longevidade; isópodos terrestres; Região Neotropical; von Bertalanffy.

Estimating animal age is an essential tool for the analysis of population dynamics, demographics, and life history. One approach to obtain this estimate is to relate age with the size of an animal's structure, which is often obtained by building growth curves (McQueEn \& Carnio 1974, Haddad \& Verani 1984). The von Bertalanffy's model (von BERTALANFFy 1938) has been successfully used for the study of the growth of peracarid crustaceans, of amphipods (DiAs \& SPRUNG 2004) as well as of terrestrial isopods (Isopoda, Oniscidea) (ARAujo \& Bond-BucKup 2004).

Achouri et al. (2003) studied growth rates of Porcellionides pruinosus (Brandt, 1833) (Porcellionidae) at Garat Nâam (Kasserine, Tunisia), where they found different lifespan and growth rates among cohorts in a natural population. Females born in the spring took 2.5 months to reach sexual maturity, whereas cohorts born in late summer and autumn took 3.5 months. In Brazil, Araujo \& Bond-Buckup (2004) studied a natural population of Atlantoscia floridana (van Name, 1940)
(Philosciidae), and built a growth curve based on the size of animals captured monthly in the field. Later, Araujo \& BondBuckup (2005) used the von Bertalanffy's method to analyze the age structure of males and females in a natural population of the same species.

McQueen \& Carnio (1974) studied the growth of Porcellio spinicornis (Say, 1818) (Porcellionidae) based on weight of individuals raised in the laboratory, whereas HADDAD \& VERANI (1984) described the growth curve of Balloniscus sellowii (Brandt, 1833) (Balloniscidae) based on the body length, instead of weight, in isopods obtained in laboratory.

The southernmost Brazilian state, Rio Grande do Sul, harbors many endemic Neotropical isopd species (ARAujo \& Zardo 1995, Araujo 1999, Lopes \& Araujo 2003, Araujo \& Lopes 2003, Araujo \& Quadros 2005). One of these species, Balloniscus glaber Araujo \& Zardo, 1995, (Balloniscidae), belongs to the Rio Grande do Sul threatened species list (Bond-Buckup et al. 
2003) due to its restricted geographical distribution. This species was recently recorded in Parque Estadual de Itapuã (AlmERÃo et al. 2006), and Quadros \& Araujo (2007) provided the first information on its ecological traits.

This study aimed at describing the von Bertalanffy growth curve of B. glaber based on field data.

\section{MATERIAL AND METHODS}

This study was carried out in the Parque Estadual de Itapuã (PEI) $\left(30^{\circ} 22^{\prime} \mathrm{S} 51^{\circ} 02^{\prime} \mathrm{W}\right)$, located in the city of Viamão, Rio Grande do Sul, Brazil (Fig. 1). PEI is a remnant of the natural landscape of this region, and is destined for conservational

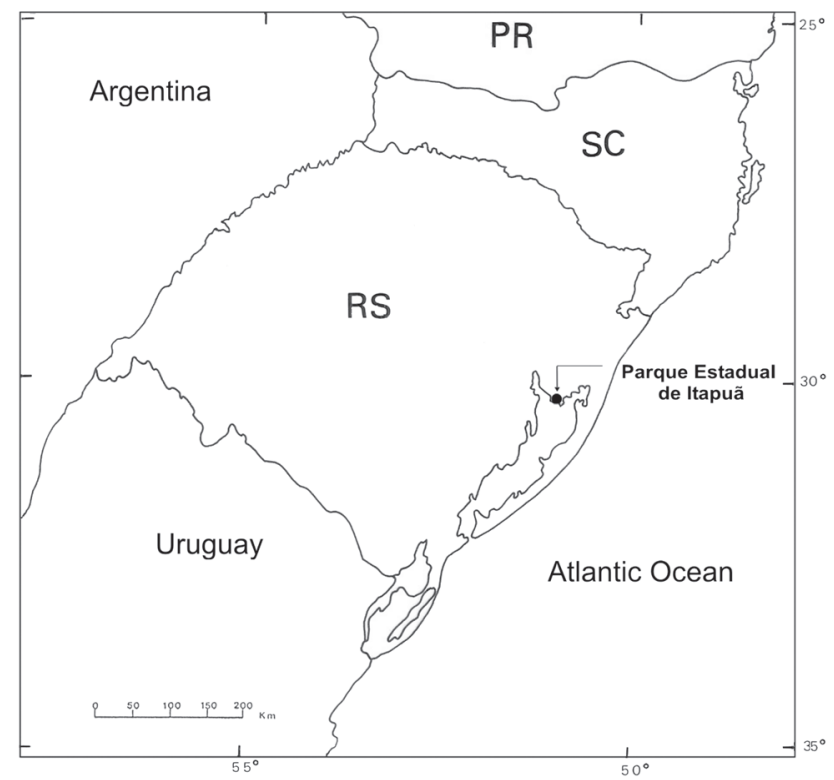

Figure 1. Map of Rio Grande do Sul, showing Parque Estadual de Itapuã, the site of sampling.

purposes (Rio Grande do Sul 1997). The climate in this region is Köppen's Cfa type (Strahler 1974).

Individuals of B. glaber were monthly captured from May 2004 to April 2005, following the sampling design described by Araujo \& Bond-Buckup (2005). An area of $216 \mathrm{~m}^{2}$ within a semideciduous forest was chosen, based on a previous study (ALMERÃO et al. 2006). Twelve samples containing soil and litter were extracted from this area with a round bottomless recipient of 707 $\mathrm{cm}^{2}$. Samples were hand-sorted in the laboratory, and then left in a Berleze's funnel extractor for $72 \mathrm{~h}$. Individuals were separated in mancas (Araujo et al. 2004a), males and females (Araujo et al. 2004b), preserved in ethanol at 70\%, and measured under a stereomicroscope. According to ARAUjo \& BOND-BUCKUP (2004), cephalothorax width was used as a measure of size, as bodylength measurements may vary within wide ranges, depending on body contraction after death (SUTTON 1968).
Von Bertalanffy's growth function (VBGF) is described by the equation $\mathrm{W}_{\mathrm{t}}=\mathrm{W}_{\infty}\left[1-\mathrm{e}^{-\mathrm{k}\left(\mathrm{t}-\mathrm{t}_{0}\right)}\right]$, where $\mathrm{W}_{\mathrm{t}}$ is cephalotorax width (in $\mathrm{mm}$ ) for a given age $\mathrm{t}$ (in days); $\mathrm{W}_{\infty}$ is the maximum mean cephalothorax width (in $\mathrm{mm}$ ); $\mathrm{k}$ is the growth rate, and $\mathrm{t}_{0}$ is a parameter related to age at length zero (also in days) (voN BERTALANFFy 1938).

Histograms were organized based on absolute size-frequency with $0.09 \mathrm{~mm}$ intervals for the mode calculation (performed using PeakFit 4.12 - SeaSolve Software Inc. ${ }^{\circledR}$ ). Cohorts were manually depicted by observing the modal displacement along months. Since cohorts are better identified by following a period of intense appearance of mancas in the population, which in our case only occurred from November 2004 (Fig. 2), we decided to repeat May 2004 to April 2005 histograms, totaling an interval of 18 months. Then, chosen modes were fitted in a linear regression using the method of Ford-Walford for unequal time intervals among monthly samplings (WALFORD 1946). In this regression, we considered Manca II as size at $t_{0}$, because Manca I can be considered as the last intramarsupial stage (ARAUJO $\&$ Bond-Buckup 2004). The resulting coefficients a and b were used to obtain $\mathrm{k}, \mathrm{W}_{\infty}$, and $\mathrm{t}_{0}$ in the following manner (FABENS 1965): $\mathrm{k}=-\mathrm{b} ; \mathrm{W}_{\infty}=-\mathrm{a} / \mathrm{b} ; \mathrm{t}_{0}=\mathrm{k}^{-1} \cdot \ln \left[\Sigma\left(\mathrm{W}_{\infty}-\mathrm{W}_{\mathrm{t}}\right) \cdot \mathrm{e}^{(-\mathrm{kt})} / \Sigma \mathrm{W}_{\infty} \cdot \mathrm{e}^{(-2 \mathrm{kt})}\right]$.

Growth curves were separately calculated for males and females. After that, curves were linearized by the method of Allen (1976), using $\mathrm{W}_{\mathrm{t}}=\mathrm{a}-\mathrm{b} \cdot \mathrm{r}^{\mathrm{t}}$, where $\mathrm{a}=\mathrm{W}_{\infty} ; \mathrm{b}=\mathrm{W}_{\infty} \cdot \mathrm{e}^{\mathrm{kt} \mathrm{t}_{0}}$ and the regression coefficient $r$ was calculated as $\left(\mathrm{e}^{-\mathrm{k}}\right.$ males $\mathrm{e}^{-\mathrm{k}}$ females $) / 2$. Linear regressions were compared using ANCOVA for a $95 \%$ confidence interval (SNEDECOR \& COCHRAN 1967). Life span was estimated based on Pinheiro \& TAdDeI (2005).

\section{RESULTS}

We obtained 1391 individuals, consisting of 191 mancas (I, II, and III), 410 males, and 790 females. The size of the Manca II individuals was about $0.68 \mathrm{~mm}$. The monthly frequency histograms are shown in figure 2 .

The modes used for building the curves (Tab. I) were chosen based on the coefficient of the fitted regression, and on the closeness of the resulting $W_{\infty}$ with the maximum cephalotorax width observed in nature $\left(\mathrm{W}_{\max }\right)$.

Table I. Mode values (cephalothorax width in millimetres) obtained for males and females of Balloniscus glaber, chosen for the VBGF.

\begin{tabular}{rcrc}
\hline \multicolumn{2}{c}{ Males } & \multicolumn{2}{c}{ Females } \\
\hline Day & Mode value & Day & Mode value \\
\hline 1 & 0.680 & 1 & 0.680 \\
60 & 0.996 & 99 & 1.175 \\
130 & 1.301 & 335 & 1.958 \\
244 & 1.710 & 518 & 2.220 \\
366 & 1.910 & 701 & 2.400 \\
549 & 2.060 & - & - \\
\hline
\end{tabular}




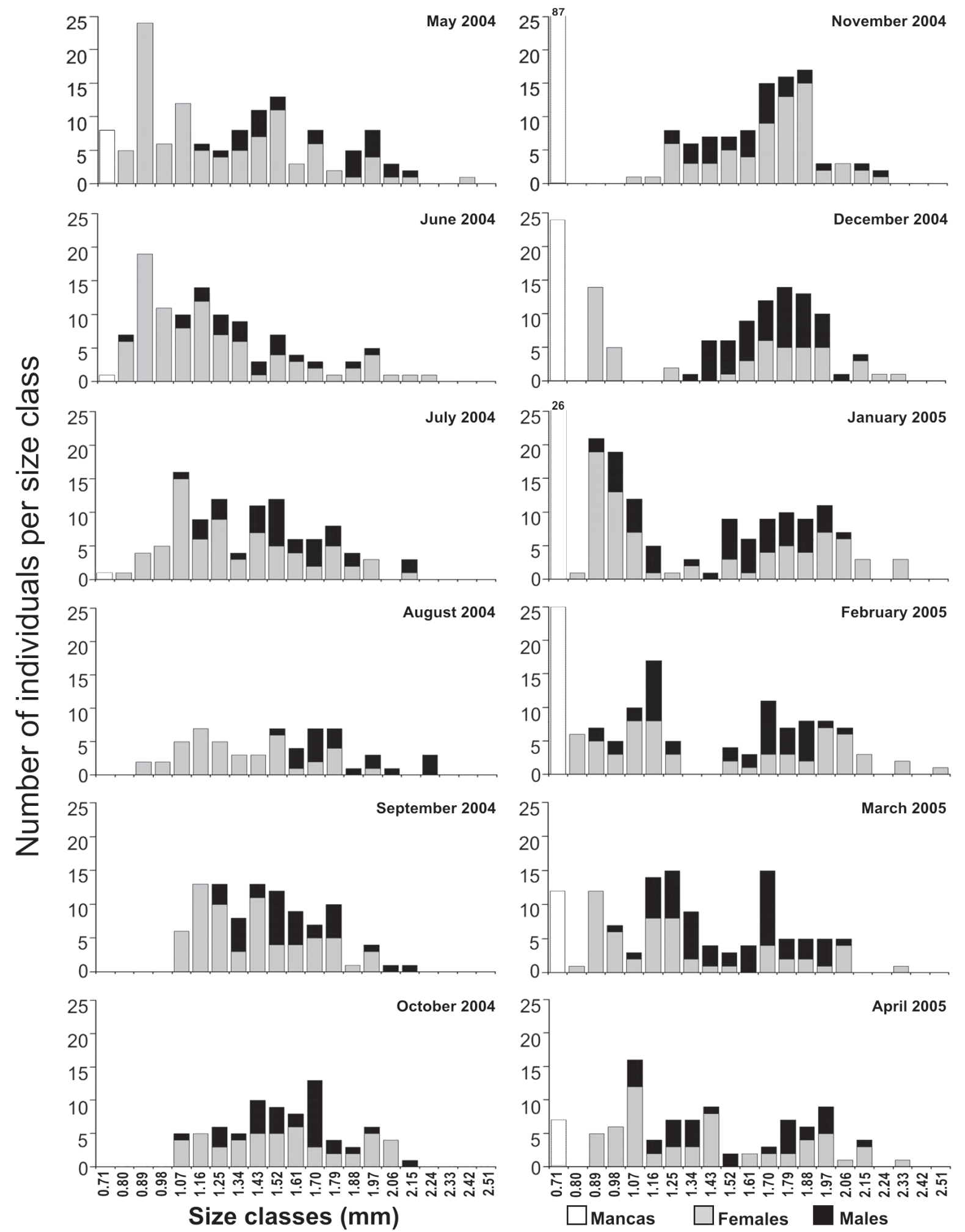

Figure 2. Frequency distribution of Balloniscus glaber cephalothorax width $(\mathrm{mm})$ in Parque Estadual de Itapuã, Rio Grande do Sul, from May 2004 to April 2005.

Revista Brasileira de Zoologia 24 (4): 1108-1112, dezembro 2007 

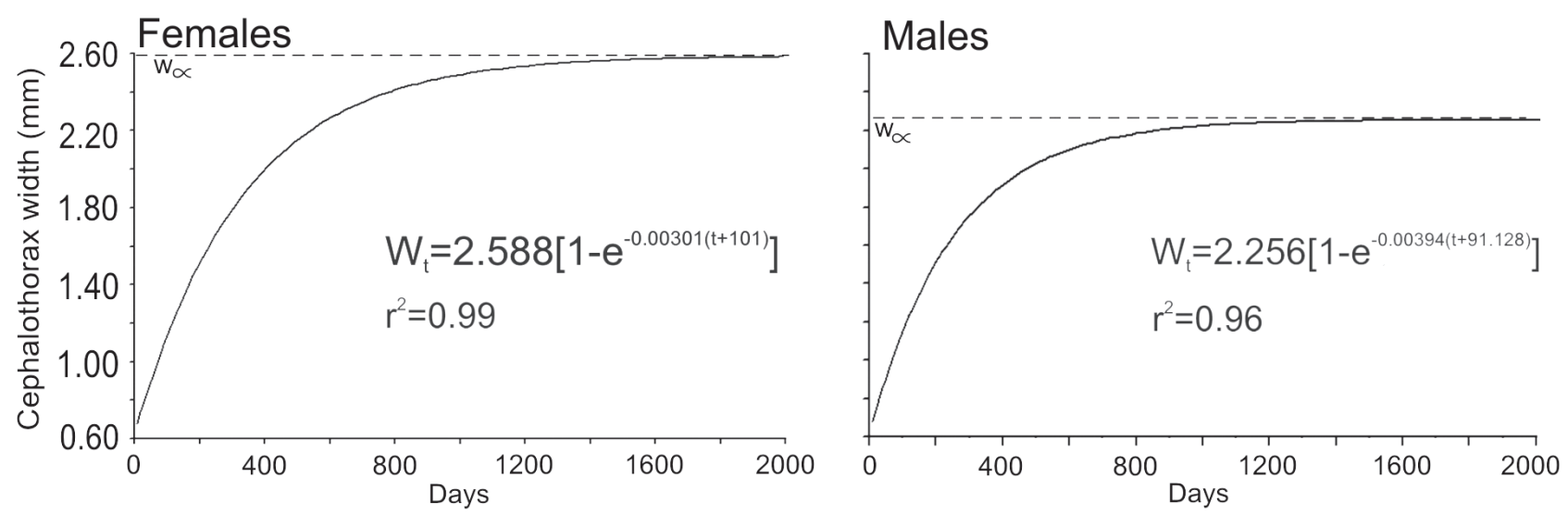

Figure 3. Balloniscus glaber growth curve in Parque Estadual de Itapuã, Rio Grande do Sul, from May 2004 to April 2005 . $W_{t}$ represents the cephalothorax width $(\mathrm{mm})$ of the individuals in time $t ; \mathrm{W}_{\infty}$ is the maximum mean cephalothorax width, $t$ is the age (days), and $\mathrm{r}^{2}$ is the coefficient of determination of the transformed regression (WALFORD 1946).

The curves for females and males (Fig. 3) are described by the following equations: $W_{t}=2.588\left[1-\mathrm{e}^{-0.00301(t+101)}\right]$ for females, and $\mathrm{W}_{\mathrm{t}}=2.256\left[1-\mathrm{e}^{-0.00394(\mathrm{t}+91.128)}\right]$ for males. According to these equations, females $\mathrm{W}_{\infty}$ was $2.58 \mathrm{~mm}$, and the $\mathrm{W}_{\max }$ was $2.47 \mathrm{~mm}$. For males, $\mathrm{W}_{\infty}$ was $2.25 \mathrm{~mm}$, whereas $\mathrm{W}_{\max }$ was $2.22 \mathrm{~mm}$.

After the linearization of male and female curves (Tab. II), a significant difference between the intercept $(\mathrm{F}=153.75$, alpha 0.05, d.f. 1.13) and the slope $(F=16$, alpha 0.05, d.f. 1.12) was verified. This finding indicates a dimorphic body size between the sexes, as well as different growth rates, that supports the separated treatment of the curves, as performed in another study (ARAUJO \& BOND-BUCKUP 2004). Life span was estimated as 28 months for males, and 36 months for females.

\section{DISCUSSION}

Dimorphic body size between males and females is a common feature of most terrestrial isopods species. As there often is a clear positive relationship between fecundity and female size (WARBURG 1993), females generally attain the largest size. This is true for several species, including Philosciidae (Araujo \& Bond-Buckup 2005), Armadillidiidae (Paris \& Pitelka 1962, AlDabagg \& Block 1981), and Porcellionidae (Nair 1998). Females achieve larger sizes at the expense of slower growth rates, and therefore live longer than males. On the other hand, males grow faster and begin to reproduce earlier than females (AcHourI et al. 2003, Araujo et al. 2004b). Tylos ponticus Grebnicki, 1874 (Tylidae) is an exception, which males achieve a larger size and live longer than females (DiAs \& SpRUNG 2003).

Von Bertalanffy's curve evidences the exponential-like growth pattern during the initial stages of terrestrial isopods. Growth rate is a key life history trait for terrestrial isopods (DANGERfield 1997). WARBURG (1993) points out that a large percentage of isopods die within their first month of life outside the brood pouch. As their mortality rates tend to decline as
Table II. Balloniscus glaber in Parque Estadual de Itapuã, Rio Grande do Sul, Brazil, from May 2004 to April 2005. Values of cephalothorax width and $r^{t}$ used to linearize the growth curve of males and females, according to AlLeN's (1976) method.

\begin{tabular}{cccc}
\hline \multirow{2}{*}{ Age (days) } & $\mathrm{r}^{\mathrm{t}}$ & \multicolumn{2}{c}{ Cephalothorax width $(\mathrm{mm})$} \\
\cline { 3 - 4 } & & Males & Females \\
\hline 120 & 0.6563 & 1.274 & 1.257 \\
210 & 0.4793 & 1.567 & 1.573 \\
300 & 0.3505 & 1.773 & 1.814 \\
390 & 0.2566 & 1.917 & 1.998 \\
480 & 0.1882 & 2.018 & 2.138 \\
570 & 0.1382 & 2.089 & 2.245 \\
660 & 0.1016 & 2.139 & 2.326 \\
750 & 0.0748 & 2.174 & 2.388 \\
840 & 0.0583 & 2.198 & 2.436 \\
\hline
\end{tabular}

body size increases (DIAS \& SpRUNG 2003), it is an advantage to minimize the time they remain small (DANGERFIELd 1997). Balloniscus glaber growth was slower than its congeneric, $B$. sellowii, and both species grew slower than A. floridana.

Most results of isopods' VBGF suggest that life span is slightly longer than two years. AcHouri et al. (2003) estimated 11 to 14 months for P. pruinosus. Araujo \& Bond-Buckup (2004) found a life span of about 28 months for A. floridana females, and 18 months for males. However, analyzing the age structure of the field population, ARAujo \& BOND-BUCKUP (2005) found that the percentage of males older than 1 year was only $0.1 \%$, whereas $1 \%$ of the females reached the $2^{\text {nd }}$ year.

Von Bertalanffy's model was adequate for the description of $B$. glaber growth curve, as it matched the general patterns of terrestrial isopods, and thus it is a valuable tool for the interpretation of their life history and population dynamics. 


\section{ACKNOWLEDGEMENTS}

To SEMA-RS (DEFAP Proj. 176); to Ludwig Buckup and Daiana Castiglioni for assistance; to FAPERGS (P.B. Araujo PROAPP Proc. 0409925; H. Meinhardt - IC scholarship) and to CAPES (scholarship to A.F. Quadros).

\section{REFERENCES}

Achouri, M.; F. Charfi-Cheikhrouha \& J.C. Marques. 2003. Biology, population structure, and field-growth rates of Porcellionides pruinosus (Brandt, 1833) (Isopoda, Oniscidea) at Garat Nâam (Kasserine, Tunisia). Crustaceana 75 (10): 1241-1262.

Al-DabagG, K.Y. \& W. Block. 1981. Population ecology of a terrestrial isopod in two breckland grass heaths. Journal of Animal Ecology 50: 61-77.

Allen, R.L. 1976. Method for comparing fish growth curves. New Zealand Journal of Marine and Freshwater Research 10: 687-692.

Almerão, M.P.; M.S. Mendonça Jr; A.F. Quadros; E. Pedó; L.G.R. Silva \& P.B. Araujo. 2006. Terrestrial isopod diversity in the subtropical Neotropics: Itapuã State Park, southern Brazil. Iheringia 96 (4): 473-477.

Araujo, P.B. 1999. Two new species of Alboscia Schultz, 1995 from Rio Grande do Sul, Brazil (Isopoda, Oniscidea, Philosciidae). Crustaceana 72 (5): 487-496.

Araujo, P.B. \& G. Bond-Buckup. 2004. Growth curve of Atlantoscia floridana (van Name) (Crustacea, Isopoda, Philosciidae) in a Brazilian restinga forest. Revista Brasileira de Zoologia 21 (1): 1-8.

Araujo, P.B. \& G. Bond-Buckup. 2005. Population structure and reproductive biology of Atlantoscia floridana (van Name, 1940) (Crustacea, Isopoda, Oniscidea) in southern Brazil. Acta Oecologica 28: 289-298.

Araujo, P.B. \& E.R.C. Lopes. 2003. Three new species of Benthana Budde-Lund (Isopoda: Philosciidae) from Brazil. Journal of Natural History 37 (20): 2425-2439.

Araujo, P.B. \& A.F. Quadros. 2005. A new species of Alboscia Schultz, 1995 (Crustacea: Isopoda: Oniscidea: Philosciidae) from Brazil. Zootaxa 1018: 55-60.

Araujo, P.B \& M.C.L. Zardo. 1995. Uma nova espécie de Balloniscus Budde-Lund (Crustacea, Isopoda, Balloniscidae) do sul do Brasil. Revista Brasileira de Zoologia 12 (4): 785-790.

Araujo, P.B.; M.M. Augusto \& G. Bond-Buckup. 2004a. Postmarsupial development of Atlantoscia floridana (van Name, 1940) (Crustacea, Isopoda, Oniscidea): the manca stages. Journal of Natural History 38 (8): 951-965.

Araujo, P.B.; A.F. Quadros; M.M. Augusto \& G. Bond-Buckup. 2004b. Postmarsupial development of Atlantoscia floridana (van Name, 1940) (Crustacea, Isopoda, Oniscidea): sexual differentiation and size at onset of sexual maturity. Invertebrate Reproduction and Development 45 (3): 221-230.

Bond-Buckup, G.; L. Buckup \& P.B. Araujo. 2003. Crustáceos, 7383. In: C.S. Fontana; G.A Bencke \& R. Reis (Eds). Livro vermelho da fauna ameaçada de extinção do Rio Grande do
Sul. Porto Alegre, EDIPUCRS, 632p.

Dangerfield, J. 1997. Growth and survivorship in juvenile woodlice: Is birth mass important? Ecography 20: 132-136.

Dias, N. \& M. Sprung. 2003. Population dynamics and production of the isopod, Tylos ponticus in a Ria Formosa saltmarsh (south Portugal). Crustaceana Monographs 2: 133-149.

Dias, N. \& M. Sprung. 2004. Population dynamics and production of the Amphipod Orchestia gammarellus (Talitridae) in a Ria Formosa saltmarsh (southern Portugal). Crustaceana 76 (9): 1123-1141.

Fabens, A.J. 1965. Properties and fitting of the von Bertalanffy growth curve. Growth 29: 265-289.

Haddad, M.A. \& L.C. Verani. 1984. Crescimento pós-marsupial de Balloniscus sellowii (Brandt, 1833) (Isopoda, Oniscidea). Dusenia 14 (4): 197-209.

Lopes, E.R.C. \& P.B. Araujo. 2003. Nova espécie de Novamundoniscus Schultz (Isopoda, Oniscidea, Dubioniscidae) para o Rio Grande do Sul, Brasil. Revista Brasileira de Zoologia 20 (4): 611-614.

McQueen, D.J. \& J.S. Carnio. 1974. A laboratory study of the effects of some climatic factor on the demography of the terrestrial isopod Porcellio spinicornis Say. Canadian Journal of Zoology 52: 599-611.

NAIR, G.A. 1998. Reproductive and population biology of Porcellio scaber (Isopoda, Oniscidea) in Benghazi, Libya. Israel Journal of Zoology 44: 399-412.

Paris, O.H. \& F.A. Pitelka. 1962. Population characteristics of the terrestrial isopod Armadillidium vulgare in California grassland. Ecology 43: 229-248.

Pinheiro, M.A.A. \& F.G. Taddei. 2005. Crescimento do caranguejo de água doce, Dilocarcinus pagei Stimpson (Crustacea, Brachyura, Trichodactylidae). Revista Brasileira de Zoologia 22 (3): 522-528.

Quadros, A.F. \& P.B. Araujo. 2007. Ecological traits of two neotropical oniscideans (Crustacea: Isopoda). Acta Zoologica Sinica 53 (2): 241-249.

Rio Grande do Sul. 1997. Secretaria da Agricultura e Abastecimento. Plano de manejo Parque Estadual de Itapuã. Porto Alegre, Departamento de Recursos Naturais Renováveis, 158p.

Snedecor, C.L. \& W.G. Cochran. 1967. Statistical Methods. Ames, Iowa State University Press, 593p.

Strahler, A.N. 1974. Physical geography. New York, Wiley International, 643p.

SuTTON, S.L. 1968. The population dynamics of Trichoniscus pusillus and Philoscia muscorum (Crustacea: Oniscoidea) in limestone grassland. Journal of Animal Ecology 37: 425-444.

VON BERTALANFF, L. 1938. A quantitave theory of organic growth (inquiries on growth laws). Human Biology 10 (2): 181-213.

WALFORD, L.A. 1946. A new graphic method of describing the growth of animals. Biological Bulletin 90: 141-147.

WARBURG, M.R. 1993. Evolutionary biology of land isopods. Berlin, Springer-Verlag, 159p.

Received in 20.VI.2007; accepted in 26.XI.2007. 